\title{
Translation of economic terms and abbreviations for websites (from project- syndicate to inosmi.ru)
}

\author{
Olga Moysova*, Svetlana Marchenko, and Anna Boyko \\ Don State Technical University, 344000, Rostov-on-Don, Russia
}

\begin{abstract}
The relevance of studying the methods and problems of translating terms, the equivalence of terms and abbreviations of economic orientation is a necessary condition for cross-language communication. Linguists are interested in studying the development of financial, economic, and managerial terminology of a peculiar language, plus studying the problems of their translation. A translation analyses is made to find peculiarities in terms interpretation on the internet. In English, as well as in Russian, the vocabulary is characterized by a variety of multicomponent terms. Most often, economic terms of the English language are derived phrases formed according to the morphological method, which present difficulties in translation and require various transformations.
\end{abstract}

\section{Introduction}

An economic text is a special type of text dedicated for the fixation, storage and transmission of economic knowledge, acting as a verbal result of the economic discursive activity that preceded its creation. Economic text' peculiarities are determined by its information intensity, effective methods and methods of rational reasoning and economic event argumentation, in addition to forecasting economic aspects.

This means that economic and financial translation requires a deep knowledge of both a foreign language and economic disciplines [1].

For example, economic translation into or from English requires knowledge of the differences between the American and British financial systems, specific abbreviations, and much more. This applies to any other language.

The most standard lexical feature of economic papers is the text saturation with terms and terminological units, as well as the presence of stable structures and abbreviations. Texts that focus not so much on native speakers of a specific language as on representatives of a major group with certain extra-linguistic science take a special place in such literature.

The term is defined as the most informative unit of natural language. And a term means an exact carrier of information about a scientific concept." [2].

"A term is an element of terminology, a term system, which is a set of all variants of a certain word or a steadily reproducible phrase that express a professional concept related to

\footnotetext{
${ }^{*}$ Corresponding author: olga-moisva@yandex.ru
} 
a certain special field of activity. The function of a term is to express a special concept." [3].

The most influential role is performed by the accuracy and competent selection of equivalents of terms submitted in the original language. The interpretation of the text should be objective. Adapting texts is also an important task. It is necessary to choose semantic constructions that will reflect the rules of a particular language as objectively as possible.

As for the structure of the terms, they are divided into:

1) simple terms;

2) word combinations;

3) stable terminological combinations;

4) terms-complex words (this includes multicomponent complex words).

Terms of the phrase: selective communication, tax system.

The point of creation of the phrase's terms is a combining the term with a concrete notion. The term has to be a common concept in order to be familiar with the initial one. Definitions that are represented by these terms are collapsed ones. It means that they equally perform both general and specific features. Thus, terminological units which are formed by these terms of the phrase cover multiple variants of the phenomenon in question and represent really peculiar

The example may be the English term tax, which means "tax, duty, fee, membership fees, burden, load, weight, bill payment, price, disapproval, censure, accusation" serving as the basis for many terms that regulate the tax fee essence: value-added tax, land-tax, expenditure tax, income tax, wealth-tax.

Being a combination of noun bases a compound word term is equal in the dictionaries forms distributable items, book value, etc.

A terminological combination consists of an adjective plus noun union, a participle with a noun, or preposition connected nouns: accounting convention, building of competencies, utilization of loses [4].

Multicomponent complex words are particularly difficult to translate. Firstly, you need to disclose the value of the main component. The context is played great role. Then, in the composition of a multicomponent complex word - term, you should find the internal terms, if any, with the words related to them.

Based on the studied material, we came to the following conclusions:

1) the term must be correlated with the context, the term is a part of the semantic whole, denoting a certain sphere of human activity;

2) the semantic features of the terms are: systematic; definitiveness, relative "freedom" from the context; brevity; unambiguity; lack of synonyms; emotional neutrality; euphony; accuracy; logic; relationship with a specific system of concepts.

3) the main requirement for the term is its unambiguity.

A very striking indicator of the economic test is the presence of abbreviations:

1. C. O. D. - cash on delivery;

2. f. a. s-free on board;

3. f. o. b-free on board;

4. C. I. F-cost, insurance and fractum;

5. GATT - General Agreement on Tariffs and Trade;

6. I/L-import license;

7. GDP - gross Domestic Product (GDP).

Abbreviation - (from the Latin abbreevio - abbreviate) - a noun consisting of shortened words that are part of the original phrase, or of cut components of the original compound word. The creation of abbreviated words of neologisms, which have significantly expanded the English language vocabulary in recent decades, demonstrates the productivity of this 
type of word formation and the economical use of language resources by native speakers.

In the modern science of language, there are several approaches to the concept's definition of "abbreviation". In the dictionary of linguistic terms edited by O. S. Akhmanova, the following definitions of the abbreviation are given:

1) (compound word). A word composed of abbreviated initial elements (morphemes) of a phrase;

2) (the initial type of compound words, an acronym). A word formed by adding the initial letters of words or initial sounds [5].

Zemskaya E. A. considers abbreviation as the formation of compound words, classifies abbreviation as a method of word formation and believes that " abbreviation is the addition of truncated bases or truncated and complete bases. When abbreviating, a derived word is created on the basis of a combination of several words that are included in it not entirely, but in parts, in an abbreviation." [6]

Many authors interpret the concept of abbreviation in their own way, but their opinions are similar in one thing: abbreviation is considered as a special way of word formation and the process of creating words with an incomplete, truncated, base (or bases), which are called abbreviations.

There are three types of basic abbreviations in English:

a) basic abbreviations with letter reading, such as BUP( British United Press), CND (Campaign for Nuclear Disarmament), etc.;

b) basic abbreviations that read like words, such as OPEC (Oil Producing European Countries);

c) basic abbreviations that match English words in their sound form.

Such basic abbreviations are named acronyms, for instance. CLASS (Computer-based Laboratory for Automated School System), NOW (National Organization of Women), etc;

There are three main reasons for the creation and distribution of abbreviations:

1) extra linguistic factors (major social shifts and scientific and technological progress);

2) intra-linguistic factors (context, common language skills of speakers, language habit, frequency of use in speech, etc.);

3) the principle of saving speech resources.

\section{Materials and Methods}

The material of the study was economic articles from the Prodject syndicate website and their translations from the inosmi website "How to Revive the WTO" and "Government Debt is not a free Lunch.

The nature of the object of research required the use of the following methods: contextual analysis, since the definition does not always allow you to get a complete idea of the term' s meaning, in this case, an analysis of a narrow or broad context is required. When determining the terminological correspondences, the method of comparison and opposition of concepts was used. "The dynamic nature of the vocabulary makes us search for dynamic criteria of normativity." [11]

For a detailed analysis of the ways to translate terms and abbreviations, we took economic articles from the Project syndicate website and their translations from the inosmi website dated December 11, 2019 and December 6, 2019: "How to Revive the WTO", "How to revive the WTO", and "Government Debt is not a free Lunch".

\section{Results}

Having studied the lexical features of economic texts, examples are given which prove that 
the most typical lexical items of economic literature is the saturation of the text with terms and terminological phrases, additionally to the presence of lexical constructions and abbreviations.

The most commonly used method of translating an economic term in these economic texts is tracing (10 examples were found):

\begin{tabular}{|c|c|}
\hline $\begin{array}{c}\text { 1) And for governments, this "junior" } \\
\text { mebt is massive relativeto the "senior" } \\
\text { sits a top it. }\end{array}$ & Rynochnyj dolg \\
$\begin{array}{c}\text { 2) Europe did during the financial crisis, and } \\
\text { Mexico and Brazil have done under duress } \\
\text { more recently. }\end{array}$ & Finansovyj krizis \\
\hline $\begin{array}{c}\text { 3) Whereby, aggressive experimentation with } \\
\text { much higher debt might cause a } \\
\text { corresponding shift inmarket sentiment } \\
\text { an example of theNobel laureate economist } \\
\text { Robert Lucas's critique that big shifts in } \\
\text { policy canbackfire owing to big shifts in } \\
\text { expectations. }\end{array}$ & Rynochnye nastroeniya \\
\hline $\begin{array}{c}\text { 4) None of the preceding arguments } \\
\text { undermine the strong case for investing now } \\
\text { in high-return infrastructure projects } \\
\text { (including in education) that more thanpay } \\
\text { for themselves in the long run. }\end{array}$ & \\
\hline $\begin{array}{c}\text { 5) True, in many advanced economies, } \\
\text { current real (inflation-adjusted) interest rates } \\
\text { on government debt are below the real rate of } \\
\text { economic growth. }\end{array}$ & \\
\hline $\begin{array}{c}\text { 6) A recent International Monetary Fund } \\
\text { study of 55 countries over the last 200 years } \\
\text { showed that although economic growth } \\
\text { exceeded interest rates on government debt } \\
\text { almost half the time, this was not a good } \\
\text { predictor of whether the surveyed countries } \\
\text { were safe from interest-rate spikes in a crisis. }\end{array}$ & investicij \\
\hline $\begin{array}{c}\text { 7) It also marks the start of an era in which } \\
\text { the WTO no longer has a functioning } \\
\text { appellate body to adjudicatetrade disputes } \\
\text { among member countries. }\end{array}$ & Funkcioniruyushchij \\
\hline 8) Of the 349 trade disputes brought & apellyacionnyj organ \\
\hline
\end{tabular}

In this example, we see a term-phrase that is translated by tracing with the use of lexical addition of the preposition, in order to comply with the rules of compatibility in the Russian language.

From the given 10 examples, 7 terms are term-phrases.

We have identified the terms translated by transliteration

- 9 cases: The term-phrase is translated by transliteration and calculus. 


\begin{tabular}{|c|c|}
\hline $\begin{array}{l}\text { 1) After all, most social-security } \\
\text { systems are debt-like in the sense that the } \\
\text { government takes money from you now, } \\
\text { and promises to pay it back with interest } \\
\text { when you are old. }\end{array}$ & socialnoe strahovanie \\
\hline $\begin{array}{l}\text { 2) Second, and perhaps even more } \\
\text { critically, the current complacency } \\
\text { regarding much higher debt implicitly } \\
\text { assumes that the next crisis will look just } \\
\text { like the last one in } 2008 \text {, when interest } \\
\text { rates on government debt collapsed. }\end{array}$ & krizis \\
\hline $\begin{array}{l}\text { 3) Interest rates are ultra-low in part } \\
\text { because global investors are starved of } \\
\text { "safe" assets that will still pay out in the } \\
\text { event of a sharp downturn or economic } \\
\text { catastrophe. }\end{array}$ & investory \\
\hline $\begin{array}{l}\text { 4) We do so by superimposing on the same } \\
\text { graph the total number of anti- dumping and } \\
\text { anti-subsidy cases lodged against Chinese } \\
\text { exporters by all other } \\
\text { WTO members from } 1995 \text { to } 2017 \text {, relative } \\
\text { to China's export volume. Since China's } \\
\text { accession in 2001, the number of such cases } \\
\text { relative to exports has declinedas China's } \\
\text { income has increased, much as the average } \\
\text { international experience would have } \\
\text { predicted. }\end{array}$ & $\begin{array}{l}\text { eksporterov } \\
\text { eksport }\end{array}$ \\
\hline $\begin{array}{l}\text { 5) The data pattern is fairly clear: as a } \\
\text { country becomes richer, there are feweranti- } \\
\text { subsidy or anti-dumping cases against it. }\end{array}$ & antisubsidirovanie \\
\hline $\begin{array}{l}\text { 6) Since December } 2001 \text {, China haslodged } \\
21 \text { cases at the WTO, or } 6 \% \text { of the total - } \\
\text { lower than its } 10.8 \% \text { share of global } \\
\text { imports in } 2018 \text {. }\end{array}$ & import \\
\hline $\begin{array}{l}\text { 7)-9) Part of the reason is that China has } \\
\text { continued to reduce tariff and non- tariff } \\
\text { trade barriers, and ease investment } \\
\text { restrictions, in accordance with - and } \\
\text { sometimes going beyond - the terms of its } \\
\text { WTO accession agreement. }\end{array}$ & $\begin{array}{l}\text { tarifnye i netarifnye torgovye } \\
\text { barery investicionnye }\end{array}$ \\
\hline
\end{tabular}

Transliteration consists in the fact that the translation reproduces the sound of the original word (terms, etc.).

In one of the a rticles there are 2 examples of transcription with partial transliteration (letter A). Russian transliteration is not possible as a result of the fact that Russian and English have different alphabets. 


\begin{tabular}{|c|c|}
\hline 1), 2) Will the United States government & Uoll strit Mehjn strit \\
again put Wall Street before Main Street \\
and honor debts to China ahead of \\
obligations to pensioners?
\end{tabular}

In this case, the street names translated by the transcription method are not terms, they are economic realities that are translated into Russian with an explanation.

When translating, the method of unambiguous equivalent correspondence was used, since this term is generally accepted:

\begin{tabular}{|c|c|}
\hline 1) Actuarially, future taxes earmarked for & nalogovyh \\
paying pensions swamp future taxes & \\
earmarked for paying debt by a significant & \\
multiple, although many governments have & \\
been trying to adjust pensions downward & \\
gradually, as Europe did during the financial & \\
crisis, and Mexico and Brazil have done & \\
under duress more recently. & \\
\hline
\end{tabular}

1. Antonymic translation-a technique used to create a more natural grammatical structure in the translation text:

1), 2) We do so by superimposing on thesame graph the total number of anti-dumping and anti-subsidy cases lodged against Chinese exporters by all other WTOmembers from 1995 to 2017, relative to China's export volume. Since China's accession in 2001, the number of such casesrelative to exports has declined as China's income has increased, much as the average international experience would have predicted.

The following term is translated using lexical omission:

\begin{tabular}{|c|c|}
\hline 1) Undoubtedly, governments in OECD & pensii \\
countries are currently paying out an average & \\
of $8 \%$ of GDP in old-age pensions, and a & \\
staggering $16 \%$ in the case of Italyand & \\
Greece. & \\
\hline
\end{tabular}

Words that are semantically redundant, that is, expressing meanings that can be extracted from the text, are most often omitted.

We selected proposals where economic terms met and studied the ways of translating these terms. The most common methods were transliteration (10 terms), tracing ( 9 terms), transcription ( 2 realities), antonymic translation (2 terms), lexical omission (1 term), and the reception of unambiguous equivalent correspondence (1 term). (See fig.1)

We selected only 3 abbreviations in both articles: 

1) With interest rates on government debt at multi-decade lows, a number of leading economists have argued that almost every advanced economy can allow debt to drift up toward Japanese levels (over 150\% of GDP even by the most conservative measure) without any great concern about long-term consequences.

When translating, the method of unambiguous equivalent correspondence was used, since this term is generally accepted.

\begin{tabular}{|c|c|}
\hline 2) Undoubtedly, governments in OECD & OEHSR \\
countries are currently paying out an average & \\
of $8 \%$ of GDP in old-age pensions, and a & \\
staggering 16\% in the case of Italy and & \\
Greece. & \\
\hline
\end{tabular}

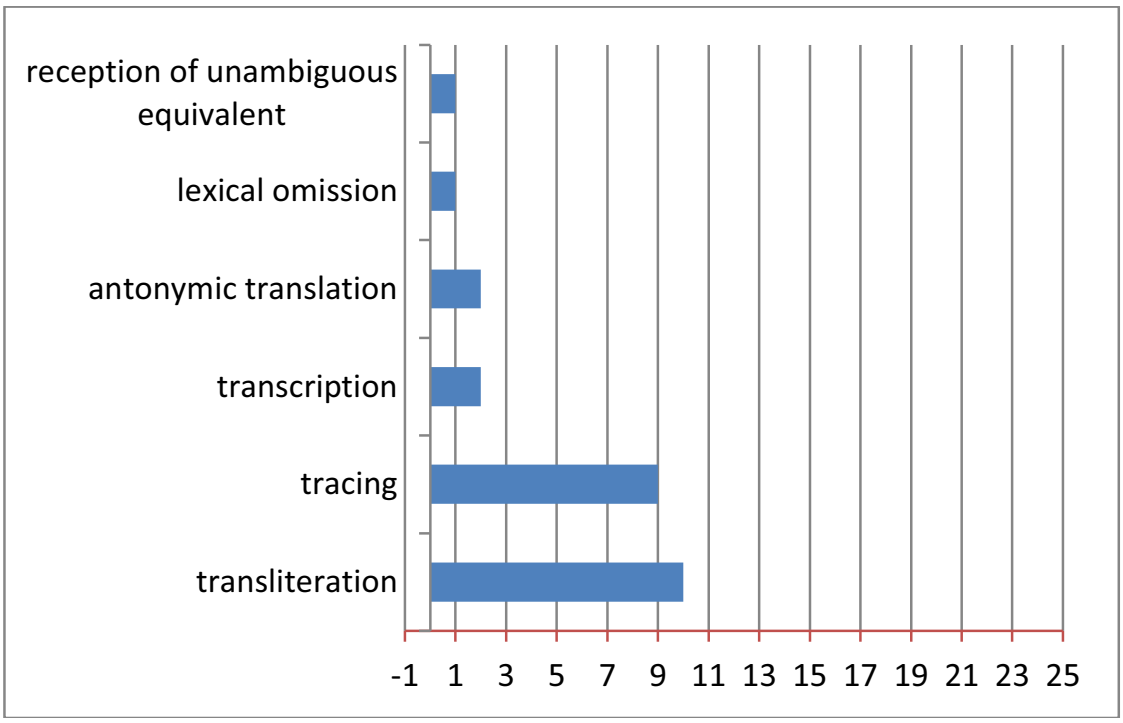

Fig. 1. Ways of translating proposals

Organization for Economic Cooperation and Development (abbr. The Organization for Economic Co-operation and Development (OECD) is an international economic organization of developed countries that recognizes the representative democracy principles and a free market economy. (Electronic resource): UPL https://ru.wikipedia.org/wiki (accessed 14.12.2019)

When translating, the method of unambiguous equivalent correspondence was used, since this term is generally accepted.

\begin{tabular}{|c|c|}
\hline $\begin{array}{c}\text { 3) NEW YORK - December 11, 2019, is the 18th } \\
\text { anniversary of China's accession to the World } \\
\text { TradeOrganization (WTO). }\end{array}$ & $\begin{array}{c}\text { Vsemirnuyu Torgovuyu } \\
\text { Organizaciyu VTO }\end{array}$ \\
\hline
\end{tabular}

When translating, the method of unambiguous equivalent correspondence was used, since this term is generally accepted. 


\section{Discussion}

Economic terms are often heard on television, and are constantly found on the Internet. Most of the key economic terms turned out to be an active vocabulary for a significant part of society. Under these conditions, there should be an increased attention to the actively forming term system.

The purpose of the study was to identify the features and methods of translating terms by comparing English and Russian texts on economic topics.

It was necessary to give the concept of an economic term as the basis of an economic text, to consider the features of the translation of economic terms; and to define the concept of abbreviation, study the features of the translation of abbreviations.

The object of the research were the financial and economic texts that were of interest in terms of identifying lexical and stylistic peculiarities of the translation of scientific texts.

The subject was the vocabulary of financial and economic texts and the identification of its features in the practice of translation.

As a result of the study of articles on financial and economic topics we selected for the analysis 25 terms and 3 abbreviations. In English and in Russian, the vocabulary is characterized by a variety of multicomponent terms. Most often, economic terms of the English language are derived phrases formed according to the morphological method, which present difficulties in translation and require various transformations.

When translating terms from English, tracing is most often used, transliteration is the second most common use, but we have encountered a literal translation.

The rarest ways of translating from English to Russian are: antonymic translation and transformation omission.

The abbreviation is usually unambiguous, and this, as already mentioned, makes it easier to translate. It should be added that currently many of the abbreviations for different references have equal or approximately equal letter (syllabic) composition, equal graphic form.

Thus, we have come to the conclusion that a translator specializing in the translation of economic documentation needs to know the abbreviations and their translation, as well as include them in their glossary and supplement it with a variety of other vocabulary. The use of such a glossary in practice will greatly facilitate and speed up the work of the translator.

\section{References}

1. L. A. Golyakova, Tekst, kontekst, podtekst (2004)

2. YU.N. Karaulov, Lingvisticheskoe konstruirovanie i tezaurus literaturnogo yazyka (2011)

3 K.YA. Averbuh, Voprosy yazykoznaniy 6, 1-49 (2012)

4 T.G. Popov, N.V. Taratynova, Ekonomicheskij tekst i ego leksicheskie osobennosti (2005)

5 O.S. Ahmanova, Slovar' lingvisticheskih terminov2, (2004)

6 E.A. Zemskaya, Sovremennyj russkij yazyk (Slovoobrazovanie, 2016)

7 How to Revive the WTO. https://www.project-syndicate.org/commentary/world-tradeorganization-revive-appellate-body-by-shang-jin-wei-and-xinding-yu-2019-12 (accessed 14.12.2019)

8. Kakvozrodit' VTO. https://inosmi.ru/economic/20191215/246442292.html (accessed 14.12.2019) 
9. Government Debt is not a free Lunch. https://www.projectsyndicate.org/commentary/government-debt-low-interest-rates-no-free-lunch-bykenneth-rogoff-2019-11 (accessed 14.12.2019)

10. Gosdolg - eto ne besplatnyj lanch» https://inosmi.ru/economic/20191211/246411419.html (accessed 14.12.2019)

11. S. Marchenko, A. Boyko, European Journal of Natural History 6, 136-139 (2016). 